\title{
International cooperative initiatives and the United Nations Framework Convention on
} Climate Change

\section{Bakhtiari, Fatemeh}

\section{Published in:}

Climate Policy

Link to article, DOI:

$10.1080 / 14693062.2017 .1321522$

Publication date:

2018

Document Version

Peer reviewed version

Link back to DTU Orbit

Citation (APA):

Bakhtiari, F. (2018). International cooperative initiatives and the United Nations Framework Convention on Climate Change. Climate Policy, 18(5), 655-663. https://doi.org/10.1080/14693062.2017.1321522

\section{General rights}

Copyright and moral rights for the publications made accessible in the public portal are retained by the authors and/or other copyright owners and it is a condition of accessing publications that users recognise and abide by the legal requirements associated with these rights.

- Users may download and print one copy of any publication from the public portal for the purpose of private study or research.

- You may not further distribute the material or use it for any profit-making activity or commercial gain

- You may freely distribute the URL identifying the publication in the public portal

If you believe that this document breaches copyright please contact us providing details, and we will remove access to the work immediately and investigate your claim 


\section{International Cooperative Initiatives and the United Nations Framework Convention on Climate Change}

Fatemeh Bakhtiari Department of Management Engineering, Technical University of Denmark, Copenhagen $\emptyset$, Denmark

With globalisation, climate change governance has become increasingly international. Today, climate change management is no longer the exclusive purview of nation-states, as non-state actors organise across national boundaries, to undertake activities that have the potential to reduce emissions of greenhouse gases. The extent to which these activities complement state-actor action is unclear. The question arises, then, of how to exploit the synergies between these two streams of climate change mitigation action, while avoiding overlaps. Several voices have suggested that the international climate change regime should play the coordinating role required to align these streams of action - under the assumption that non-state actor action can be significant, and additional to state-actor action. The paper looks at these two issues in particular, and puts forward an alternative view on the topic.

\section{THE INTERNATIONAL CLIMATE CHANGE REGIME}

The governance model upon which the United Nations Framework Convention on Climate Change (UNFCCC) was founded may have become obsolete, as so-called nonstate actor (NSA) actions continue to gain prominence. The extent to which this may be true, and what the best revisions to that governance model might be, are key issues for the international community to resolve.

Section 1.1 introduces non-state actor actions, a growing set of initiatives for climate change management. Section 1.2 outlines the linkages between these initiatives and state-actor actions, namely the activities conducted under the aegis of the UNFCCC. 


\subsection{Greenhouse-gas mitigation actions outside of the United Nations Framework Convention on Climate Change}

Climate change management initiatives outside of the UNFCCC are generally referred to as NSA actions (UNEP, 2013). NSA actions are climate change mitigation (and adaptation) actions led by actors other than states (national governments), even though states, at various jurisdictional levels, may take part in them.

NSA actions represent alternative governance schemes that complement and sometimes replace traditional schemes based on the law enforcement power of nation-states. The origin of such alternative governance schemes can be traced back to the mid-1970s, with the incipient globalisation that followed the liberalisation of international financial markets. In the area of climate change, NSA actions go back at least 25 years, with the creation of the Climate Alliance, a coalition of sub-national governments. With its focus on public-private partnerships, the 2002 World Summit on Sustainable Development spurred the creation of many additional NSA actions. They received renewed interest on the occasion of the 2009 and 2014 conferences of the parties to the UNFCCC. ${ }^{1}$

NSA actions are reflected in the UNFCCC through the so-called Durban Platform for Enhanced Action which, under its 'workstream 2', seeks to "enhance ambition in the pre-2020 period" (UNFCCC, 2012). Negotiations under this workstream revolve around, among other issues, exploring the greenhouse-gas emissions mitigation potential of non-UNFCCC actions that help curb global warming (UNFCCC, 2014).

A large number of NSA actions were launched in September 2014, on the occasions of the so-called UN Climate Summit, convened by the United Nations Secretary-General. Many more have been initiated since. ${ }^{2}$ The UNFCCC administers a repository of information, named the non-state actor zone for climate action (NAZCA, for short), which highlights the number and breadth of coverage of existing NSA actions (UNFCCC, 2015).

\footnotetext{
${ }^{1}$ This interest has spurred the creation of initiatives such as the so-called Galvanizing the Groundswell of Climate Actions, a series of open dialogues that seek to promote effective and efficient NSA actions. ${ }^{2}$ Concerns have been raised about the danger of "overcrowding" in some sectors, should the number of NSA actions in those sectors grow further (Barnsley \& Ahn, 2014). The same authors claim that increased collaboration is needed in some sectors, with a view to establishing synergies and preventing duplication of efforts. This would entail re-framing existing actions, to reflect global needs more fully (as opposed to a focus on the priorities of the largest economies).
} 
Currently, the NAZCA portal includes over 12,000 "commitments" (UNFCCC, 2015). The following seven clusters capture the vast majority of the initiatives registered in the NAZCA portal: companies (such as the Carbon Disclosure project), cities (such as the C40 Cities initiative, or the Covenant of Mayors), regions (such as the States and Regions Alliance), economic sectors (such as the Cement Sustainability Initiative, the Global Fuel Economy Initiative, or the Zero Routine Flaring project), pollutants (such as the Global Methane Initiative, or the Climate and Clean Air Coalition), forests (such as the UNREDD programme), and international transport (such as the initiatives convened by the International Civil Aviation Organization or the International Maritime Organization).

While reducing emissions of greenhouse gases is a key goal of most NSA actions, it is often not their only goal, or even the main one (UNFCCC, 2015). Notwithstanding, from the point of view of climate change mitigation, evaluating the merits of the actions entails being able to measure the size of the additional emission reductions that they bring about. ('Additional' here means reductions in greenhouse-gas emissions that would not have occurred in the absence of the action.) Besides, cost-effectiveness should arguably play a role in an evaluation of the success of the action: for a given allocation of financial and human resources, did a particular action achieve as much as it could have, in terms of greenhouse-gas emission reductions?

Three main factors hamper such an evaluation. Firstly, a great deal of NSA actions lack quantified targets or, indeed, even explicit targets (UNFCCC, 2015). Secondly, there appears to be a great deal of overlap between NSA actions and greenhouse-gas mitigation efforts undertaken under the UNFCCC, which calls into question the additionality of the emission reductions achieved (UNEP, 2015b ; PBL, 2015). Thirdly, monitoring, reporting and verification procedures associated with NSA actions vary widely among actions, and are generally weak, thus precluding any attempts at quantifying in detail the impact of the actions (Norden, 2014).

A further shortcoming of NSA actions relates to issues of legitimacy and institutional fit. Legitimacy concerns ultimately refer to the extent to which actions are both inclusive in their membership, and accountable to members. Concerns about institutional fit refer to overlaps in goals (between two actions, or between one action and the UNFCCC's mandate), and the extent to which NSA actions serve well specified functional needs (as 
opposed to responding to political or commercial interests). While generalisations are not possible, an analysis based on a sample of ICIs highlights that most are effective from a technical standpoint, but score rather low on a set of indicators related to legitimacy and institutional fit (Widerberg \& Pattberg, 2015).

International cooperative initiatives (ICIs) are a sub-set of NSA actions, characterised by their scope (international), and the number of participants (two or more). These two attributes - scope and number of participants - suggest that ICIs may be able to deliver larger greenhouse-gas emission reductions, compared to other NSA actions. For this reason, ICIs have attracted the most attention among both scholars and climate change negotiators. ${ }^{3}$

\subsection{Governance issues around the international climate change regime}

While the UNFCCC remains the main governance structure aimed at curbing climate change, ICIs have emerged as a parallel governance mechanism for climate change management (Bulkeley et al., 2014 ; Widerberg \& Stenson ,2013). De facto, therefore, several climate change governance structures coexist. It has been suggested that this trend is likely to persist and may spur more effective climate change management, compared to a single, all-encompassing governance regime, which may prove neither politically feasible, nor desirable (Keohane \& Victor, 2011).

Many have suggested that the UNFCCC is well placed to coordinate ICIs (Blok et al., 2012). For example, establishing 'minimum standards' for ICIs, with a view to ensuring that "only initiatives with a clear and verifiable mitigation potential are considered", has been proposed as an immediate task for the UNFCCC to undertake (Widerberg \& Pattberg, 2015). Further, it has been suggested that a comprehensive framework should be set up, to govern all aspects related to ICIs, notably issues related to "benchmarking and review and follow-up procedures beyond mere passive registration" (Chan et al. 2015a).

\footnotetext{
${ }^{3}$ ICIs have been promoted by, among others, private sector entities (for example, the World Business Council for Sustainable Development's Action2020 initiative), non-governmental organisations (for example, the Climate Bonds initiative), or a mix of actors.
} 
Some analysts suggest more radical changes in the governance model for climate change management: they claim that the UNFCCC "is much better equipped to provide rules for climate protection activities, and should consciously expand this feature to improve its impact", as opposed to taking a more hands-on role (Hermwille et al., 2015). They advocate that the current regime "should be complemented with another treaty" one that would "allow the pioneers of climate protection to move ahead and enjoy the benefits of cooperation", while "the dynamics generated through such a club approach could be fed back into the UNFCCC, leading to increased ambition by others in future commitment cycles" (Hermwille et al., 2015).

Finally, it has been suggested that ICIs could "offer an effective channel for public climate finance" (Norden, 2014). The appeal of this proposal presumably lies in the demand-driven and targeted nature of (some of) the initiatives. Arguably, the accountability of the initiatives would have to be improved, in some cases significantly, for this proposal to enjoy widespread acceptance. In practice, to a certain extent ICIs already serve as channels for climate finance. Notable examples are the Climate and Clean Air Coalition, or the UN-REDD Programme. Therefore, the question is whether or not scaling-up this model would increase the overall effectiveness of the international climate change regime.

\section{A REVIEW OF THE LITERATURE ON THE EMISSION REDUCTION POTENTIALS ASSOCIATED WITH INTERNATIONAL COOPERATIVE INITIATIVES}

A number of studies have reviewed ICIs, including from the point of view of quantifying the emissions reduction potential associated with the initiatives (Blok et al., 2012 ; Norden, 2014 ; PBL, 2015 ; UNEP, 2015b). These studies highlight two main issues. Firstly, efforts by cities and regions, which represent a relatively small subset of the total number of initiatives, appear to hold over one-third of the overall emissions reduction potential. Secondly, none of the initiatives has delivered a significant share of the emission reductions to which they have committed (in the few cases where those reductions are quantified). 
Overlap among ICIs appears to be small: between $0.2 \mathrm{Gt} \mathrm{CO}_{2} \mathrm{e}$ in 2020 (UNEP, 2015b), and $0.3 \mathrm{Gt} \mathrm{CO}_{2} \mathrm{e}$ in 2030 (PBL, 2015). The extent to which ICIs overlap with emission reduction efforts under the UNFCCC is uncertain, but believed to be quite large (UNEP, 2015a). By one estimate, the overlap could represent $1.8 \mathrm{Gt} \mathrm{CO}_{2} \mathrm{e}$ in 2020 and $3.8 \mathrm{Gt} \mathrm{CO}_{2} \mathrm{e}$ in 2030 , or roughly 70 percent of total greenhouse-gas emission reductions in that year (PBL, 2015). The largest overlap is expected in the clusters 'companies' and 'cities', while little or no overlap is expected in the clusters 'international transport' and 'pollutants' (PBL, 2015).

The following paragraphs summarise, by type, the scope of selected initiatives. Where possible, estimates of potential greenhouse-gas emission reductions are indicated (Table 1).

Companies. The top 1,000 companies in terms of greenhouse-gas emissions account for about $10 \mathrm{Gt} \mathrm{CO}_{2}$ e annually, or 20 percent of global greenhouse-gas emissions, with almost a quarter of companies having joined one or more ICIs (Wouters, 2013). Among the main company-focused initiatives are: the Business Environmental Leadership Council (made up of 32 United States corporations adopting voluntary emission reductions commitments), the WWF Climate Savers (a programme providing advice to 28 global companies), Caring for Climate (a United Nations-sponsored initiative to raise awareness about climate change among its 399 corporate members), and the Carbon Disclosure Project (an effort to measure and report business performance on climate change on behalf of its investor signatories). By one estimate, based on the data available through the Carbon Disclosure Project, implementation of the commitment by a group of companies accounting for about 15 percent of all corporate emissions of greenhouse gases would result in savings of about $0.7 \mathrm{Gt} \mathrm{CO}_{2} \mathrm{e}$ in 2020 and $1.3 \mathrm{Gt} \mathrm{CO}_{2} \mathrm{e}$ in 2030, compared to a reference scenario (PBL, 2015). Overall, signatories of most company initiatives seem to be on track to meet their commitments (UNEP, 2015b).

Cities. Urban areas are the source of between 71 and 76 percent of global, energyrelated greenhouse-gas emissions (Seto et al., 2014). Among the main urban-focused initiatives are: the carbonn Climate Registry (a voluntary reporting platform for use by local and subnational governments), the C40 Cities Initiative (a network of 75 large cities committed to implementing voluntary greenhouse-gas emission reductions), and 
the Covenant of Mayors (a network of over 5,000 cities committed to implementing voluntary greenhouse-gas emission reductions). It is estimated that the C40 Cities Initiative could reduce emissions by $0.4 \mathrm{Gt} \mathrm{CO}_{2} \mathrm{e}$ in 2020, whereas the Covenant of Mayors could result in emission reductions worth $0.3 \mathrm{Gt} \mathrm{CO}_{2} \mathrm{e}$ in 2020 (PBL, 2015). Since the base year for reporting varies from one signatory to another, even within the same initiative, assessing progress toward the target is challenging (UNEP, 2015b).

Regions. The Climate Group, a non-for-profit organisation, convenes regional governments from across the globe under the aegis of the so-called States and Regions Alliance. The Alliance is made up of sub-national governments such as the states of New York and California in the United States, the state of São Paulo in Brazil, and the provinces of Lombardy and Emilia-Romagna in Italy. Alliance members commit to "limit emissions to below eighty to ninety-five percent below 1990 levels, or below two metric tonnes per capita, by 2050" (TCG, 2015). ${ }^{4}$ Alliance members represent about one-eighth of the global economy and, partly because of this, their commitments, if met, would result in relatively large greenhouse-gas emission reductions of around $0.75 \mathrm{Gt} \mathrm{CO}_{2} \mathrm{e}$ in 2020 (UNEP, 2015b).

Economic sectors. Among the many initiatives that are relevant to quarrying and manufacturing businesses, a few are specific to certain branches. In terms of potential emission reduction volumes, the most important are: the Cement Sustainability Initiative (a voluntary greenhouse-gas emission reductions commitment by 24 major cement producers, representing 30 percent of the market), the Global Fuel Economy Initiative (a partnership of six international organisations offering outreach, research, and policy support to developing country governments), the Zero Routine Flaring Project (a partnership among oil companies, national governments, and development institutions), and the Ultra-low $\mathrm{CO}_{2}$ Steelmaking Initiative (a consortium of 48 European steel-manufacturing companies, and related organisations, conducting research and development in a coordinate manner). Full implementation of these initiatives would result in the following greenhouse-gas emission reductions: $0.1 \mathrm{Gt} \mathrm{CO}_{2} \mathrm{e}$ in 2030 (Cement Sustainability Initiative), $0.5 \mathrm{Gt} \mathrm{CO}_{2} \mathrm{e}$ in 2030 (Global Fuel Economy Initiative)

\footnotetext{
${ }^{4}$ Stated differently, alliance members commit to limit their emissions to a level that is lower than a fraction (eighty to ninety-five percent) of their respective emission levels in 1990, or to a level that is below two metric tonnes per capita, by 2050.
} 
and $0.1 \mathrm{Gt} \mathrm{CO}_{2} \mathrm{e}$ in 2030 (Zero Routine Flaring Project) (PBL, 2015). No estimate is available for the Ultra-low $\mathrm{CO}_{2}$ Steelmaking Initiative.

Pollutants. Some initiatives target specific pollutants, irrespective of the emitting sources, because greenhouse-gas mitigation techniques are similar across sources. The most important are: the Global Methane Initiative (a partnership of governments, industries, and development finance institutions to promote methane recovery from fossil fuel production, transport, agriculture, and waste), the Climate and Clean Air Coalition (an alliance between 54 national governments and 54 non-governmental entities that promote cost effective approaches for reducing emissions of black carbon), and the proposal for including hydrofluorocarbons (HFCs, for short) in the Montreal Protocol of Substances that Deplete the Ozone Layer (a proposal by some parties to the Montreal Protocol, by which the use of HFCs as substitutes for chlorofluorocarbons would be phased out, since HFCs have high global warming potentials). The Global Methane Initiative could result in savings of $1.2 \mathrm{Gt} \mathrm{CO}_{2} \mathrm{e}$ in 2030 , whereas the phasing

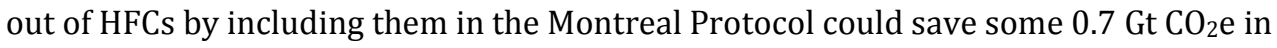
2030 (PBL, 2015). The Climate and Clean Air Coalition does not have any specific emission reduction targets. Besides, black carbon is not covered in international climate change negotiations and, for this reason, any emission reductions resulting from implementation of the activities of the Climate and Clean Air Coalition, while mitigating climate change, would not count toward international climate change mitigation targets.

Forests. In as much as forests act as sinks of carbon dioxide emissions, several initiatives concern forestry and land use management. The most important are: the Bonn Challenge (a platform bringing together several reforestation and afforestation efforts, notably the UN-REDD programme, with the overall goal of restoring 150 million hectares of deforested and degraded lands by 2020), and the New York Declaration of Forests (a partnership that involves national governments, multinational companies, and civil society organisations seeking to halve natural-forest loss by 2020 , by changing agricultural practices that currently entail deforestation). It is estimated that the Bonn Challenge could save between $0.2 \mathrm{GtCO}_{2} \mathrm{e}$ and $0.4 \mathrm{GtCO}_{2}$ e by 2020 (UNEP, 2015b). Yet, current pledges only account for 39 percent of the overall goal (UNEP, 2015b). The New York Declaration of Forests could save as much as $0.7 \mathrm{GtCO}_{2}$ by 2030 (PBL, 2015). 
International transport. In 2012 emissions of greenhouse gases from international aviation and international shipping accounted for between three and four percent of the total (EP, 2015). Emission reduction efforts from international aviation and international shipping are governed by mandatory energy efficiency requirements put forward by, respectively, the International Civil Aviation Organization, and the International Maritime Organization. Implementation of the measures that each organisation is currently advocating could result in emission reductions of $0.3 \mathrm{Gt} \mathrm{CO}_{2} \mathrm{e}$

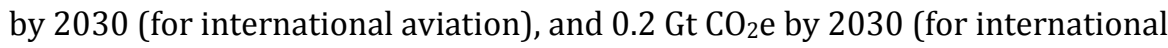
shipping) (PBL, 2015).

The quantitative studies referred to in this section conclude that the performance of ICIs (in terms of greenhouse-gas emission reductions) is limited. This conclusion contrasts with the main findings of a further assessment, more qualitative in nature, which suggests that "most climate actions have performed well in terms of producing outputs, putting them on track to implementing their commitments in the coming years" (Chan et al., 2015b). ${ }^{5}$ Echoing this discrepancy, some authors argue for a stronger emphasis on ex-post data collection, which can underpin a more robust assessment of the performance of the various initiatives. These authors conclude that, at present, such assessment is not possible (Widerberg \& Stripple, 2016).

Nonetheless, a number of recent studies have sought to estimate the aggregated impact of a selection of ICIs (those deemed to hold the largest emissions reduction potential). Typically, this kind of analyses focus on selections of ten to twenty initiatives. Most studies report estimates in the order of a few hundred mega tonnes of carbon dioxide equivalents (UNEP, 2016). A recent study puts forward significantly higher estimates: between six and eleven giga tonnes of carbon dioxide equivalents by 2030 (Graichen et al., 2016). These estimates are calculated on the assumption that all initiatives considered reach their stated goals, and emission reductions by the initiatives do not displace emission reductions elsewhere. For comparison, full implementation of all UNFCCC party commitments would amount to greenhouse-gas emission savings of between nine and eleven giga tonnes of carbon dioxide equivalents by 2030 (UNEP, 2016).

${ }^{5}$ A recent working paper (Graichen et al., 2016), referred to below, subscribes this view. 
Concerted and dedicated efforts will be needed to reduce the uncertainty around these estimates. Three types of efforts may be particularly warranted:

- Hale (2016) postulates that "to the extent they overlap, nonstate actions reinforce, implement, and give credibility to the national pledges". To reap synergies more fully, it would seem reasonable to expect that national pledges take stock of, and review, related ICIs. A cross-comparison of this kind could help generate additional emission reductions-potential data.

- Chan and colleagues (2016) draw attention to a particular type of ICIs - those that, while having limited short-term greenhouse-gas emission reduction potentials, may be able to offer large emission reductions in the longer term. Special care must be taken when quantifying the potential of this kind of initiatives, as those estimates are particularly sensible to forecasts about uncertain socio-economic developments.

- Graichen and colleagues (2016) assess "good practice" in reporting by a selection of international cooperative initiatives, to find that initiatives focused on forestry (such as the Bonn Challenge, or the New York Declaration on Forests) score highest. Clearly, as highlighted in section 3.2, guidance and performance standards will be needed to ensure reliable measurements of (i) emission reductions by one initiative, and (ii) emission reductions elsewhere catalysed by the initiative.

Table 1: Examples of emission reduction potential estimates, by sector

\begin{tabular}{|l|c|c|}
\hline Sample initiatives & \multicolumn{2}{|c|}{$\begin{array}{c}\text { Estimated emission reduction } \\
\text { potentials (Gt CO }\end{array}$ e) } \\
\hline & 2020 & 2030 \\
\hline Companies & 0.70 & 1.30 \\
\hline - Carbon disclosure project (PBL, 2015) & & \\
\hline Cities & 0.40 & \\
\hline - C40 cities initiative (PBL, 2015) & 0.30 & \\
\hline - Covenant of Mayors (PBL, 2015) & & \\
\hline Regions & 0.75 & \\
\hline - States and Regions Alliance (UNEP, & & \\
\hline
\end{tabular}




\begin{tabular}{|c|c|c|}
\hline 2015b) & & \\
\hline \multicolumn{3}{|l|}{ Economic sectors } \\
\hline $\begin{array}{l}\text { - Cement Sustainability Initiative (PBL, } \\
\text { 2015) }\end{array}$ & & 0.10 \\
\hline $\begin{array}{l}\text { - Global Fuel Economy Initiative (PBL, } \\
\text { 2015) }\end{array}$ & & 0.5 \\
\hline - $\quad$ Zero Routine Flaring Project (PBL, 2015) & & 0.10 \\
\hline \multicolumn{3}{|l|}{ Pollutants } \\
\hline - $\quad$ Global Methane Initiative (PBL, 2015) & & 1.20 \\
\hline - $\quad$ HFCs phase-out (PBL, 2015) & & 0.70 \\
\hline \multicolumn{3}{|l|}{ Forests } \\
\hline - $\quad$ Bonn Challenge (UNEP, 2015b) & $0.20-0.40$ & \\
\hline $\begin{array}{l}\text { New York Declaration of Forests (PBL, } \\
\text { 2015) }\end{array}$ & & 0.70 \\
\hline \multicolumn{3}{|l|}{ International Transport } \\
\hline - International aviation (PBL, 2015) & & 0.30 \\
\hline - International shipping (PBL, 2015) & & 0.20 \\
\hline
\end{tabular}

\section{DISCUSSION}

Even though the literature on ICIs is relatively scant, some trends are beginning to emerge. They highlight the need to improve (i) our understanding of ICIs, and (ii) international climate change governance mechanisms.

Great expectations are being placed on the ability of ICIs to deliver significant greenhouse-gas emission reductions. ${ }^{6}$ Yet, for most ICIs, there is no evidence as to the level of greenhouse-gas emissions reductions, additional or otherwise, that the initiatives may be able to deliver. Section 2 in this paper goes some way into documenting this point. Not least, the literature consistently suggests that, to deliver more effectively, ICIs have to be coordinated and should meet certain 'minimum performance standards' (Hsu et al., 2016).

With regard to the UNFCCC, most authors suggest that its role has to be revised, to accommodate the emergence of ICIs. There is no evidence to support the claim that the

\footnotetext{
${ }^{6}$ Some authors even claim that the initiatives can contribute to more effective review processes under the
} Paris Agreement (van Asselt 2016). 
UNFCCC may be able to effectively promote the aforementioned goals (Victor, 2016). Arguably, the UNFCCC and its subsidiary bodies are ill-equipped to serve hundreds of very diverse initiatives, each with its own goals and governance mechanisms. Not least, the UNFCCC has no legal relationship with the initiatives, through which it could wield some kind of influence on them. What is more, establishing such relationships would most likely undermine the initiatives' reason d'être - flexibility and limited oversight, among others.

Some authors argue that the UNFCCC should promote and coordinate the development (and implementation, presumably) of minimum performance standards for ICIs (Hsu et al., 2016). It is equally unlikely that the UNFCCC can help promote 'minimum performance standards' with non-parties, where it is struggling to articulate monitoring, reporting and verification mechanisms (a sort of 'performance standards') for its own parties.

\subsection{Potential elements of an ICI coordination mechanism}

This paper claims that actors other than the UNFCCC are better placed to coordinate ICIs, and help develop 'performance standards' for them. Having the initiatives do this by themselves would be one option, even if it resulted in a multi-layered approach, where some initiatives live-up to higher standards than others. Having a third party play that role would be a second option (for example, the United Nations Environment Programme - UNEP - , which manages the CIP database of international cooperative initiatives).

The UNEP has a long history of acting as neutral broker to facilitate agreement among different types of actors, as well as in convening expert panels and consultative groups. The Global Reporting Initiative is a 20 year old testimony to the former, and the Emissions Gap Report represents a high-profile example of the latter.

The UNEP's experience and expertise could be brought to bear for the coordination of international cooperative initiative. This might entail a mapping of current initiatives, building on the CIP database, to identify overlaps. It may further entail the definition of 
operation- and performance-criteria, to promote effective and efficient delivery. ${ }^{7}$ Arguably, such UNEP-facilitated framework should aim at raising standards and reaping synergies, rather than being all-encompassing, in the sense of including all possible initiatives.

\subsection{Possible research areas for the short- and mid-terms}

This paper claims that ICIs will only move from hype to success if they can demonstrate that (i) the greenhouse-gas emission reductions attributable to them are additional to those associated with emission reduction efforts conducted under the aegis of the UNFCCC, and (ii) their actions support and multiply actions by the UNFCCC.

Beyond the governance questions outlined in section 3.1, this calls for monitoring, reporting and verification procedures that are not only workable and scientifically sound, but also accepted by all parties. Specifically, these procedures should be able to identify (and prevent) double-counting of emissions, not only between ICIs and national emissions reduction commitments under the UNFCCC, but also between different ICIs with overlapping scope.

Effectiveness constitutes a second key issue on which additional research is needed: from an effectiveness point of view, decisions concerning the allocation of resources should in principle prioritise the initiatives that deliver larger emission reductions. Such normative view clashes with two realities. Firstly, while some ICIs deliver greenhousegas emission reductions, climate change mitigation is not their primary purpose. For these initiatives, emissions-reduction criteria are unlikely to drive resource allocation decisions. Secondly, public relations, rather than climate change mitigation, is arguably the true motivation behind several initiatives that have greenhouse-gas emission reductions as their stated goal (this is notably the case for initiatives that lack any kind of specific targets). For these initiatives, effectiveness considerations are secondary to their primary public relations rationale.

\footnotetext{
${ }^{7}$ The latter would most likely touch upon the types and frequency of reporting that are relevant to each sector.
} 
The literature puts forward a number of criteria for assessing the effectiveness of ICIs those that have climate change mitigation as their true primary goal. The proposals by Harrison et al. (2015) are among the most comprehensive. It is understood that performance with regard to greenhouse-gas emission reductions would add to these two elements.

Further work is needed to capture the full complexity of the initiatives. Specifically, effectiveness criteria need to reflect issues such as the adequacy of the initiatives' stated goals and time tables, or the stringency of the accountability mechanism considered.

Time frames constitute a further element that requires research: for a given budget, the pace at which emissions can be reduced varies across gases, sectors and world regions a consideration that effectiveness criteria should reflect. 


\section{REFERENCES}

Blok, K., Höhne, N., van der Leun, K., \& Harrison, N. (2012). Bridging the greenhouse-gas emissions gap. Nature Climate Change, 2(7), 471-474.

Barnsley, I. and S. Ahn (2014). Mapping Multilateral Collaboration on Low-Carbon Energy Technologies, IEA Insights Series 2014. International Energy Agency. Paris: OECD/IEA.

Bulkeley, H., Andonova, L., Betsill, M. M., Compagnon, D., Hale, T., Hoffmann, M. J., Newell, P., Paterson, M., Roger, C. \& VanDeveer, S. D. (2014). Transnational climate change governance. Cambridge University Press. Cambridge, United Kingdom.

Chan, S., Asselt, H., Hale, T., Abbott, K. W., Beisheim, M., Hoffmann, M., Guy, B., Höhne, N., Hsu, A., Pattberg, P. \& Pauw, P. (2015a). Reinvigorating international climate policy: A comprehensive framework for effective nonstate action. Global Policy, 6(4), 466-473.

Chan, S., Falkner, R., van Asselt., H., Goldberg, M. (2015b). Strengthening non-state climate action: a progress assessment of commitments launched at the 2014 UN Climate Summit. Centre for Climate Change Economics and Policy Working Paper No. 242. Grantham Research Institute on Climate Change and the Environment Working Paper No. 216.

Chan, S., Brandi, C., \& Bauer, S. (2016). Aligning Transnational Climate Action with International Climate Governance: The Road from Paris. Review of European, Comparative \& International Environmental Law, 25(2), 238-247.

EP (2015). Emission Reduction Targets for International Aviation and Shipping (IP/A/ENVI/2015-11). European Parliament. Brussels, Belgium and Strasbourg, France.

Graichen, J., Healy, S., Siemons, A., Höhne, N., Kuramochi, T., Gonzales-Zuñiga, S., Sterl, S., Kersting, J., Wachsmuth, J. (2016). Climate initiatives, national contributions and the Paris Agreement. Fraunhofer-Institut für System- und Innovationsforschung and NewClimate Institute. Karlsruhe and Cologne, Germany.

Hale, T. (2016). "All Hands on Deck": The Paris Agreement and Nonstate Climate Action. Global Environmental Politics. 
Harrison, N., Bartlett,N., Block, K., Gardiner, A., Levin ,K., Elliott, C. (2015). Tracking International Cooperative Initiatives. Nordic Council of Ministers. Copenhagen, Denmark. Hermwille, L., Obergassel, W., Ott, H. E., \& Beuermann, C. (2015). UNFCCC before and after Paris-what's necessary for an effective climate regime? Climate Policy, 1-21.

Hsu, A., Cheng, Y., Weinfurter, A., Xu, K., \& Yick, C. (2016). Track climate pledges of cities and companies. Nature, 532(7599), 303-306.

Keohane, R. O., \& Victor, D. G. (2011). The regime complex for climate change. Perspectives on politics, 9(01), 7-23.

Norden (2014). Enhancing Ambition through International Cooperative Initiatives. Nordic Council of Ministers. Copenhagen, Denmark.

PBL (2015). Climate action outside the UNFCCC - Assessment of the impact of international cooperative initiatives on greenhouse gas emissions. PBL Netherlands Environmental Assessment Agency. The Hague, Netherlands.

Seto K.C., S. Dhakal, A. Bigio, H. Blanco, G.C. Delgado, D. Dewar, L. Huang, A. Inaba, A. Kansal, S. Lwasa, J.E. McMahon, D.B. Müller, J. Murakami, H. Nagendra, \& A. Ramaswami, (2014). Human Settlements, Infrastructure and Spatial Planning. In: Climate Change 2014: Mitigation of Climate Change. Contribution of Working Group III to the Fifth Assessment Report of the Intergovernmental Panel on Climate Change [Edenhofer, O., R. Pichs-Madruga, Y. Sokona, E. Farahani, S. Kadner, K. Seyboth, A. Adler, I. Baum, S. Brunner, P. Eickemeier, B. Kriemann, J. Savolainen, S. Schlömer, C. von Stechow, T. Zwickel and J.C. Minx (eds.)]. Cambridge University Press, Cambridge, United Kingdom and New York, United States.

TCG (2015). Compact of States and Regions - disclosure report 2015. The Climate Group. London, United Kingdom.

UNEP (2013). The Emissions Gap Report 2013 - a UNEP synthesis report. United Nations Environment Programme. Nairobi, Kenya.

UNEP (2015a). The Emissions Gap Report 2015 - a UNEP synthesis report. United Nations Environment Programme. Nairobi, Kenya. 
UNEP (2015b). Climate commitments of subnational actors and business: a quantitative assessment of their emission reduction impact. United Nations Environment Programme. Nairobi, Kenya.

UNEP (2016). The Emissions Gap Report 2016 - a UNEP synthesis report. United Nations Environment Programme. Nairobi, Kenya.

UNFCCC (2012): Decision 2/CP.18 - Advancing the Durban Platform

(FCCC/CP/2012/8/Add.1). United Nations Framework Convention on Climate Change. Bonn, Germany.

UNFCCC (2014): Decision 1/CP.20 - Lima Call for Climate Action

(FCCC/CP/2014/10/Add.1). United Nations Framework Convention on Climate Change. Bonn, Germany.

UNFCCC (2015): The Non-State Actor Zone for Climate Action (NAZCA) portal. Available online at: http://climateaction.unfccc.int/

Van Asselt, H. (2016). The role of non-state actors in reviewing ambition, implementation, and compliance under the Paris Agreement. Climate Law, 6(1-2), 91-108.

Victor, D. G. (2016). What the Framework Convention on Climate Change teaches us about cooperation on climate change. Politics and Governance, 4(3), 133-141.

Widerberg, O., \& Stenson, D. E. (2013). Climate clubs and the UNFCCCO - Complement, bypass or conflict? FORES Study 2013:3.

Widerberg, O., Pattberg, P. (2015). International Cooperative Initiatives in Global Climate Governance: Raising the Ambition Level or Delegitimizing the UNFCCC?. Global Policy, 6(1), 45-56.

Widerberg, O., Stripple, J. (2016): The expanding field of cooperative initiatives for decarbonization: a review of five databases. Wiley Interdisciplinary Reviews: Climate Change 2016, Volume 7, Issue 4, pp. 486-500. doi: 10.1002/wcc.396.

Wouters, K. K. (2013): Wedging the Gap-An analysis of the impact of existing large-scale bottom-up initiatives for greenhouse gas emission mitigation in 2020. Utrecht University. Utrecht, Netherlands. 